\title{
Screening porcine DNA in collagen cream cosmetic products
}

\author{
${ }^{2}$ Zabidi, A.R., ${ }^{2}$ Fauzi, F.N., ${ }^{2}$ Abd Razak, F.N., ${ }^{1}$ Rosli, D., ${ }^{1}$ Jamil, M.Z.M., \\ ${ }^{1}$ Wan Ibrahim, W.K. and ${ }^{1,2, *}$ Yahaya, N. \\ ${ }^{1}$ International Fatwa and Halal Center (iFFAH), Universiti Sains Islam Malaysia, 71800 Bandar Baru \\ Nilai, Negeri Sembilan, Malaysia \\ ${ }^{2}$ Faculty of Science and Technology, Universiti Sains Islam Malaysia, 71800 Bandar Baru Nilai, Negeri \\ Sembilan, Malaysia
}

\author{
Article history: \\ Received: 15 August 2019 \\ Received in revised form: 4 \\ December 2019 \\ Accepted: 22 December \\ 2019 \\ Available Online: 10 \\ February 2020
}

\section{Keywords:}

Collagen,

Cosmetics,

Porcine,

PCR,

Species-specific primer

\section{DOI:}

https://doi.org/10.26656/fr.2017.4(S1).S05

\begin{abstract}
Pig derivatives such as collagen are commonly added as an ingredient in cosmetics to improve appearance and skin health. To ensure cosmeceutical products comply with halal regulations in Muslim countries, the development of a quick, valid, practical, and economical method to detect the presence of porcine DNA is necessary. The aim of this study was to detect the presence of pork DNA from cosmetic product. Genomics DNA from highly processed cosmetics cream products and raw meat (as positive control) were isolated by using Wizard Genomic DNA purification kit from Promega. Five cosmetics cream samples that labeled as collagen cream were purchased through the online store. One of the products is declared contains piggy collagens, one is halal and other three are unknown source. Polymerase chain reaction (PCR) assay was performed to amplify the fragment of the $12 \mathrm{~S}$ rRNA gene by a set of species-specific primer which produces amplicons length $387 \mathrm{bp}$ in porcine DNA. The result showed the presence of porcine DNA which was isolated from raw pork, cream cosmetics that contain piggy collagens and cream hands that contains collagen from unknown source using commercially PCR MyTaq ${ }^{\mathrm{TM}}$ DNA polymerase kit and a set of species-specific primer with an annealing temperature of $44.4^{\circ} \mathrm{C}$. The band produced from this PCR was the highest intensity. The success of the amplification of porcine DNA shows that this method is practical, easy and efficient for routine product analysis for halal authentication in undeclared and declared of the porcine material presence in the product. Hence, consuming cosmetic cream contains porcine DNA is prohibited according to the Islamic view in Malaysia.
\end{abstract}

\section{Introduction}

Halal food and cosmetics become major contributor in the global halal market. It showed rapid increase with the increase in the Muslim population. According to the Islamic view, non halal substance can be changed to halal through 'Istihlak' and 'Istihlak' processes. 'Istihlak' is the theory of the decomposition of matter (substance) in which a substance decomposes after mixing with other substances. As an example, the ritually unclean (najs) water that is added into a lot of clean water is deemed as clean if the water is colorless, odorless and no unpleasant smell (European Research and Fatwa Council, 2013). 'Istihlak' is a change of a ritually unclean (najs) substance to another substance (pure) naturally or through an intermediary thereby altering the whole characteristic including the name, nature and form (Al-Ghananim and 'Izzat, 2008).
Fatty acids, glycerin and collagen from pig are the most common ingredients found in body lotions, cream and mask packs (Yorgancioglu and Bayramoglu, 2013). Collagen is a protein that can be obtained from flesh and connective tissues of mammal. Hydrolyzed collagen, which also known as collagen powder is used in collagen -based product. Hydrolyzed collagen can be turn into smaller molecules after the breaking down process of its chemical structure (Mohammad et al., 2014). The smaller molecules is required in cosmetic creams to make it is easy to absorb into the bloodstream (Rodríguez et al., 2017). The primary structure of collagen which consists of 20 amino acid, is known as the smallest molecules found in collagen (Schrieber and Gareis, 2007).

Pig mask cream collagen product (Elizavecca Green Piggy Collagen Jella) contains $50 \mathrm{~g}$ pig collagen which is 
used for reducing the appearance of wrinkles on the skin. It is labeled as non halal product. According to 'Istihlak' process, the non halal material that went through physically and chemically changes can turn into halal. However, it is believed that amino acid composition of hydrolysed collagen in pig mask cream collagen product is remained intact and unchanged, although it involves extreme condition such as heat treatment. Therefore, pork material that can be detected after 'Istihlak' process remained as Haram (Jamaludin et al., 2011). We use $12 \mathrm{SP}$ and $12 \mathrm{SFW}$ primers to amplify mitochondrial encoded gene $12 \mathrm{~S}$ rRNA. Previously, it had been reported the annealing temperature for $12 \mathrm{SP}$ and $12 \mathrm{SFW}$ primers to amplify $12 \mathrm{~S}$ rRNA gene was $63{ }^{\circ} \mathrm{C}$ (Rodríguez et al., 2003). Hence, this study was designed to optimize the annealing temperature of species-specific primer 12S rRNA to increase the sensitivity of (limit of detection, LOD) and determine the lowest concentration of pork DNA (LOD) that can be detected by PCR in five cream collagen products.

\section{Materials and methods}

\subsection{Sample preparation}

Raw meat pork and pork sausage were used as a positive control in this study and was purchased from Tesco supermarket located at Bandar Baru Nilai. Five cosmetics cream contain collagen were purchased through online store. One of the product is declared contains pig collagens, one is halal and other three are of unknown source. The five cosmetics were Elizavecca Green Piggy Collagen Jella pack pig mask cream collagen product $(100 \mathrm{~mL})$, Brightening cream SPF15 with authorized Halal logo $(100 \mathrm{~mL})$, Collagen Hand Cream $(100 \mathrm{~mL})$, Whitening Face Cream $(100 \mathrm{~mL})$ and Collagen Plus Vit E Day and Night cream $(100 \mathrm{~mL})$.

\subsection{DNA extraction}

DNA was extracted from pork sausage and five cosmetics cream by using Wizard Genomic DNA purification kit (Promega Corporation, Madison, USA). The DNA extraction was performed according to the manufacturer's instructions with slight modifications. A $600 \mu \mathrm{L}$ of Nuclei Lysis solution was added into the centrifuge tube. Subsequently, $20 \mathrm{mg}$ of raw porcine and cream were added to chilled nuclei Lysis and incubated at $65^{\circ} \mathrm{C}$ for 15 mins. At room temperature, $200 \mu \mathrm{L}$ of protein precipitation solution were added and vortex at high speed for $20 \mathrm{~s}$. The sample was chilled on dry ice for 5 minutes, followed by centrifugation for 4 mins at $13400 \mathrm{rpm}$. The supernatant containing DNA was transferred to a microcentrifuge tube containing $600 \mu \mathrm{L}$ of isopropanol and mixed gently by inversion until the white thread-like strands of DNA formed. The supernatant was removed. Then, at room temperature, $600 \mu \mathrm{L}$ of $70 \%$ ethanol was added and gently inverted to wash the DNA followed by centrifugation for $1 \mathrm{~min}$. Ethanol was carefully removed. The tube was dried on clean absorbent paper and incubated at $65^{\circ} \mathrm{C}$ with the lid open to evaporate the ethanol. Upon completion, $25 \mu \mathrm{L}$ of DNA rehydration solution was added and the DNA was rehydrated by incubating overnight at $4^{\circ} \mathrm{C}$. The extracted DNA was stored at $2-8{ }^{\circ} \mathrm{C}$ for further analysis (Promega Corporation, 2017).

\subsection{DNA quantification and purity}

The quality and quantity of the extracted DNA material were determined by spectrophotometry, using BioDrop DUO UV/VIS Spectrophotometer. DNA concentration was determined by UV absorbance at 260 $\mathrm{nm}$ and the purity of the extracted DNA was determined by the ratio of absorbance at 260 and $280 \mathrm{~nm} .0 .5 \mu \mathrm{L}$ of the DNA rehydration was placed on the detector and served as a blank sample followed by extracted DNA samples.

\subsection{DNA qualitative analysis by gel electrophoresis}

Agarose gel 1.0\% (w/v) was used for determining the presence of DNA and the size of PCR products. The gel was placed in the electrophoresis chamber and added with $1 \times$ TAE buffer. Then, $10 \mu \mathrm{L}$ of each sample for analysis ( $9 \mu \mathrm{L}$ added with $1 \mu \mathrm{L}$ loading dye, Promega) was prepared and loaded into the lane by using a micropipette. All agarose gels in this experiment used DNA $1 \mathrm{~kb}$ Gene Ruler Ladder (Thermo Fisher Scientific, United States) as the size marker and was ran at $99 \mathrm{~V}$ for 35 mins. The process was continued with gel visualization using Bio-Rad Universal Hood II Gel Doc System and the digital image was obtained.

\subsection{Oligonucleotide Primer}

PCR primers for the amplification of porcine DNA were as described by Rodriguez et al. (2003). The oligonucleotide primers used in this study was porcine specific DNA primers of 12SFW and 12SP (Table 1). This set of primers produced amplicons of $387 \mathrm{bp}$ length, respectively.

Table 1. Characteristics and properties of primer

\begin{tabular}{cclc}
\hline Primer & Length & \multicolumn{1}{c}{ Sequence $\left(5^{\prime}-3^{\prime}\right)$} & Used as \\
\hline 12SP & 23 & GTTACGACTTGTCTCTTCGTGCA & \multirow{2}{*}{ Porcine specific } \\
12SFW & 26 & CCACCTAGAGGAGCCTGTTCT(AG)TAAT & \\
\hline
\end{tabular}

Source: Rodriguez et al. (2003) 


\subsection{Polymerase Chain Reaction (PCR) amplification} assay

The extracted DNA was then tested by PCR assay using PCR MyTaq ${ }^{\mathrm{TM}}$ DNA polymerase kit from BIOLINE. The components for PCR reaction is shown in Table 2. Pure porcine DNA was used as a positive control while distilled water was used as a negative control. Amplification was performed using forward and reverse primer on a Mastercycler nexus PCR cycler, programmed to perform a denaturation step of $93^{\circ} \mathrm{C}$ for 2 mins, followed by 30 cycles consisting of $30 \mathrm{~s}$ at $93^{\circ} \mathrm{C}$ for denaturation, $30 \mathrm{~s}$ at $40^{\circ} \mathrm{C}$ to $70{ }^{\circ} \mathrm{C}$ for primer annealing, and $45 \mathrm{~s}$ at $72^{\circ} \mathrm{C}$ for extension. The last extension step was 5 mins longer. PCR products were electrophoresed in a $1.0 \%(\mathrm{w} / \mathrm{v})$ agarose gel. The resulting DNA fragments were visualized by Bio-Rad Universal Hood II Gel Doc System.

Table 2. Components for PCR reaction

\begin{tabular}{lc}
\hline \multicolumn{1}{c}{ Component } & $\begin{array}{c}\text { Volume of Each component in } 25 \\
\mu \mathrm{L} \text { of PCR mixture, }(\mu \mathrm{L})\end{array}$ \\
\hline $5 \times$ MyTaq Reaction Buffer & 5 \\
$10 \mu$ M Forward primer & 0.5 \\
$10 \mu$ M Reverse primer & 0.5 \\
MyTaq DNA Polymerase & 0.5 \\
Template DNA & 5 \\
Water $\left(\mathrm{dd} \mathrm{H}_{2} \mathrm{O}\right)$ & 13.5 \\
\hline
\end{tabular}

Source: MyTaq ${ }^{\mathrm{TM}}$ DNA Polymerase protocol

\subsection{Limit of detection (LOD)}

The sensitivity of the PCR was performed by serial dilution of DNA template of porcine. The replicate of PCR measurements was made series dilution with concentrations of $0.1,0.01,0.001,0.0001 \mathrm{ng} / \mu \mathrm{L}$ of porcine DNA template. PCR was performed as already described to investigate the sensitivity of the PCR by running the lowest concentration of DNA on $1 \%(\mathrm{w} / \mathrm{v})$ agarose gel. The repeatability assay was performed by replication of these dilution series in triplicates.

\section{Results and discussion}

\subsection{Optimization of DNA extraction using Wizard genomic DNA purification kit}

Genomic isolation of pork sausage was optimized. After optimization of genomic isolation, DNA of porcine derivatives from a cosmetic sample was extracted by using Wizard $\AA$ Genomic DNA Purification Kit (Promega, Madison,WI, USA). The presence of porcine DNA in the cosmetic product named Elizavecca Green Piggy Collagen Jella pack pig mask was verified. The extracted DNA was analyzed, and the quantity of DNA obtained was evaluated by using the spectrophotometer and gel electrophoresis (Figure 1, Table 3).

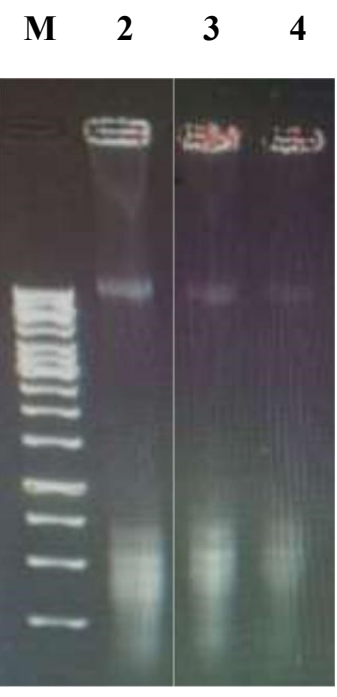

Figure 1. Electrophoresis gel of extracted DNA from pork sausage: lane 1: $1 \mathrm{~Kb}$ marker $(\mathrm{M})$, lane 2-4: extracted DNA from pork sausage.

Table 3. Quantification of DNA extraction using BioDrop DUO UV/VIS Spectrophotometer

\begin{tabular}{cccc}
\hline Sample & Replicate & A260/A280 & $\begin{array}{c}\text { Concentration } \\
\mathrm{ng} / \mu \mathrm{L}\end{array}$ \\
\hline \multirow{2}{*}{ Pork Sausage } & 1 & 1.891 & 50.94 \\
& 2 & 1.817 & 48.92 \\
Average & 3 & 1.884 & 46.88 \\
\hline \multirow{2}{*}{ Cosmetic } & 1 & 1.864 & 48.91 \\
& 2 & 1.31 & 4.222 \\
Average & 3 & 1.398 & 3.512 \\
\hline
\end{tabular}

It has been reported that isolation of DNA from rice and corn by using Wizard Genomic DNA Purification System kit from Promega is more efficient, high DNA yield and purity when compared with $\mathrm{CTAB}$ method (Hanum et al., 2018). However, the most suitable extraction kit for the isolation of porcine DNA from cosmetics is Power PrepTM DNA when compared with CTAB method, Nucleo spin food kit, QIAamp DNA stool mini kit, TIANamp Genomic DNA kit, and Wizard Genomic DNA purification kit (Kim et al., 2018). DNA detection method real time-PCR with DNA concentration $2.28 \times 10^{0}$ copies and $\mathrm{Ct}$ values 39.07 was generated on porcine DNA isolated from cosmetic creams by using Power PrepTM DNA extraction kit. It was claimed that Power PrepTM DNA extraction kit was more efficient than other extraction kits because the kit uses chloroform during the extraction process. It indicates that chloroform or hexane was used to treat oil and waxes simultaneously in lipid-rich cosmetics such as cream to reduce PCR inhibition (Kim et al., 2018).

Similarly, the result in this study indicates that Wizard Genomic DNA purification kit contributes to a lower concentration of DNA especially from the cosmetic product as compared to pork sausage. 
However, the low DNA concentration of cosmetic showed by UV/VIS spectrophotometer (3.252-4.222 ng/ $\mu \mathrm{L})$ satisfyingly to perform PCR assay. Conversely, compared to the previous study by Hanum et al. (2018), the isolation of DNA from unprocessed food and processed food gave significantly high DNA yields and purity of DNA, however, when it was applied to the cream-based product, the purity of DNA and DNA yields was lower. This may be due to the over-processing of the sample or low extraction efficiency for a collagen-based product which is generally present in the form of protein.

Analysis of extracted DNA from cosmetic products on BioDrop DUO UV/VIS Spectrophotometer showed the ratio of absorbance at 260 and $280 \mathrm{~nm}$ were in the range of 1.0 to 1.4 indicating contamination with protein (Table 3). The origin of isolated DNA could reflect the poor purity of DNA. It has been suggested that since cosmetic cream is a highly processed product, it seems like it contains only small amounts of highly degraded DNA. Besides, the sample used contained collagen from pigskin as an ingredient which presence in form of smallest molecules structure. Collagen protein is a structural protein of extracellular matrix that present in the skin, tendon and bone of the vertebrate body. It exists in the body in an insoluble macromolecular structure and combines with proteoglycan, glycoprotein, and etc. Thus, the preparation of collagen protein includes: the selection of the materials, pre-process, extraction, separation, and purification (Yang and Shu, 2014).

Elizavecca Green Piggy Collagen Jella pack pig mask had been chosen in the study since this product is labeled with Piggy Collagen. In this study we would like to validate is the Piggy Collagen can be detected by using the DNA detection approach. Hypothetically, raw material in the highly processed product can be transformed into other product after physical and chemical treatments. However, in this study after successfully isolated the DNA from Elizavecca Green Piggy Collagen Jella pack pig mask, we believed the chemical composition of hydrolyzed collagen remains

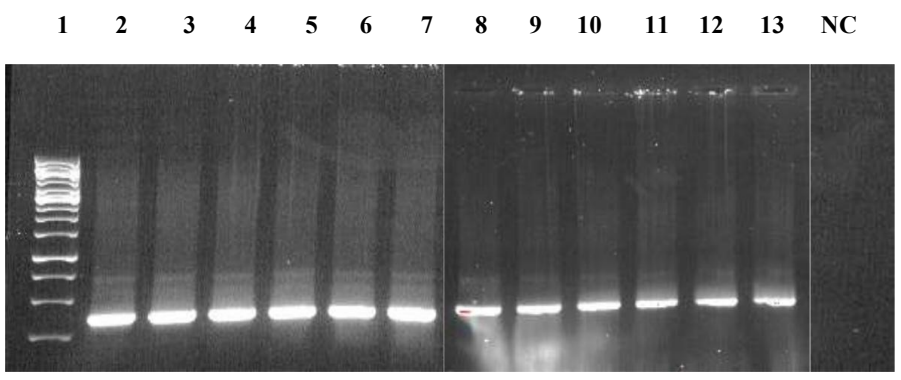

Figure 2. Electrophoretic analysis of PCR product with different annealing temperature range from $40^{\circ} \mathrm{C}$ to $50^{\circ} \mathrm{C}$ visualized on $1.0 \%(\mathrm{w} / \mathrm{v})$ gel electrophoresis. Lane $1: 1 \mathrm{~kb}$ marker, lanes 2-13: Extracted genomic DNA from pork sausage, lane 14: negative control (NC). unchanged. We suggest that heat treatment, alcohol, acid, alkali or heavy metals could only disrupt the tertiary and secondary structure of the protein and do not break the peptides bond and amino acids. Thus, the amino acid molecules in hydrolyzed collagen are not affected by physical or chemical treatment. However, the recent study shows that Porcine DNA cannot be detected in Lard-adulterated cream when amplified using species - specific primers (Abd-Gani et al., 2018).

\subsubsection{Gradient PCR to determine the optimum annealing temperature of specific primer}

Porcine DNA was amplified by polymerase chain reaction (PCR) using a species-specific primer. These forward and reverse primers were designed to allow binding to the porcine DNA, efficient isolation from genomic DNA and amplification of the specific target sequence only. Gradient PCR was carried out in order to obtain the optimum annealing temperature for the primer to bind to the target sequence.

Based on the electrophoretic analysis, at a temperature range of $40^{\circ} \mathrm{C}$ to $50^{\circ} \mathrm{C}$, the entire lane (2-13) of gel in Figure 2 showed the presence of the expected porcine DNA fragment which was around $387 \mathrm{bp}$. This indicated that the DNA was successfully amplified. At temperature range between $50^{\circ} \mathrm{C}$ to $60^{\circ} \mathrm{C}$ revealed the visible DNA fragment of porcine but starting from lane 10 to 13 the band became fainted (Figure 3). As the intensity of this band decreased with further increasing temperature, there was no specific band synthesized when the temperature rose from $60^{\circ} \mathrm{C}$ to $70^{\circ} \mathrm{C}$. This demonstrated that the primer did not amplify porcine DNA at temperature rose to $58^{\circ} \mathrm{C}$ above. Overall, the results revealed that $12 \mathrm{SP}$ and $12 \mathrm{SFW}$ primers can anneal only at the temperature range from $40^{\circ} \mathrm{C}-59.7^{\circ} \mathrm{C}$. The temperature of $44.4 \mathrm{C}$ showed the highest band intensity (Figure 2). Hence, it was selected as the optimum annealing temperature and can be used for subsequent PCR assay. Conversely, the annealing temperature obtained was not as stated by Rodriguez et

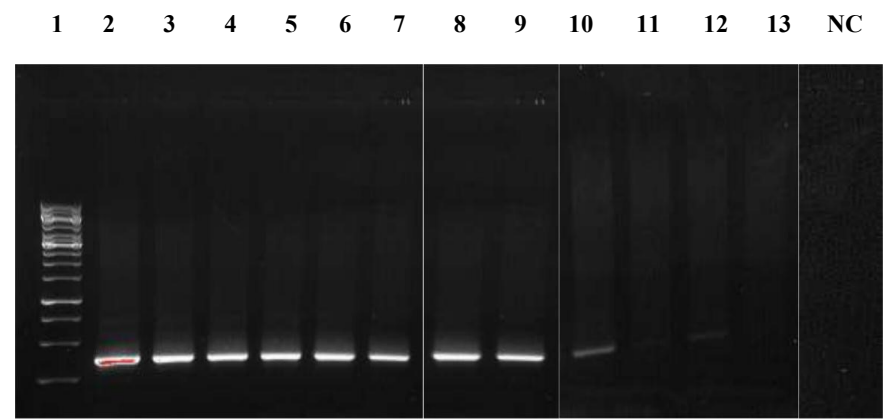

Figure 3. Electrophoretic analysis of PCR gradient temperature ranging from $50^{\circ} \mathrm{C}$ to $60^{\circ} \mathrm{C}$ visualized on $1.0 \%$ (w/v) gel electrophoresis. Lane 1: $1 \mathrm{~Kb}$ Marker, Lanes 2 to 13: Extracted porcine genomic DNA from pork sausage, Lane 14: Negative control (NC). 
al. (2003). Rodriguez et al. (2003) mentioned the annealing temperature for $12 \mathrm{SP}$ and $12 \mathrm{SFW}$ primers to perform was $63^{\circ} \mathrm{C}$ which is different from the results obtained in this study.

\subsection{Limit of Detection}

A sample of pork sausage (as control) was analyzed for the detection limit of PCR assay by species-specific primer. PCR amplification was performed on the serial dilutions of porcine DNA comprising $0.1,0.01,0.001$ and $0.0001 \mathrm{ng} / \mu \mathrm{L}$. It was observed that the higher dilution of DNA, the lower the intensity of the band obtained in PCR with species-specific primer. Although the concentration of DNA was low, it still provided sufficient information to be examined. A detection limit (lower percentage producing visible DNA amplification) of $0.01 \%$ was achieved for porcine DNA (Figure 4). Each dilution series can provide good amplification up to $0.001 \mathrm{ng} / \mu \mathrm{L}$ but the intensity of band decreasing at dilution of $0.0001 \mathrm{ng} / \mu \mathrm{L}$.

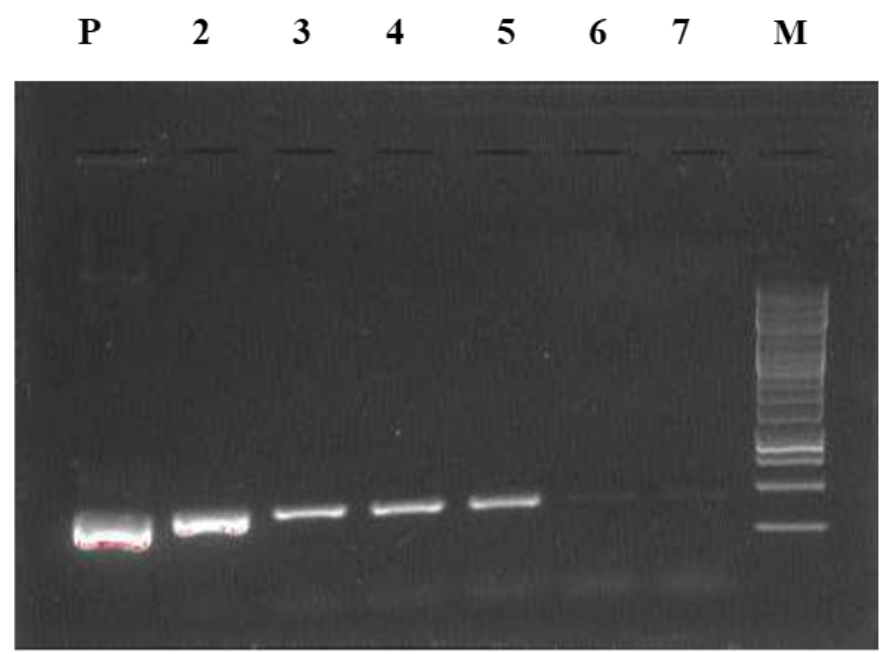

Figure 4. Electrophoretic analysis of the $12 \mathrm{~S}$ rRNA PCR products amplified from the experimental serial dilution of standard genomic DNA of porcine. Lane 1: positive control (P), lane 2: dilution of $0.1 \mathrm{ng} / \mu \mathrm{L}$, lane 3-5: $0.01 \mathrm{ng} / \mu \mathrm{L}$, lane 67: $0.001 \mathrm{ng} / \mu \mathrm{L}$ of extracted DNA from pork sausage, lane 8: $1 \mathrm{~Kb}$ marker $(\mathrm{M})$

\subsection{Detection of pork derivatives in cream}

PCR amplification of DNA isolated from cosmetic creams with an annealing temperature of $44.4^{\circ} \mathrm{C}$ resulted in $387 \mathrm{bp}$ of PCR product which is amplified from the $12 \mathrm{~S}$ rRNA gene by using a porcine-specific primer (Figure 5). This result is consistent with Rodríguez et al. (2003). The resulting outcome indicates that the process of extraction and preparation for PCR reaction using the optimized method of PCR assay with species-specific primer (12SP and 12SFW) was successfully amplified (Rodríguez et al., 2003).

Species-specific primer is a primer that only effects or react to particular species. Many PCR-based assays for species identification use mitochondrial DNA for DNA target template (mtDNA). This is because relatively high amount mtDNA is found in mitochondrion than to DNA in cell nucleus or nuclear DNA. It also contains a greater accumulation of point mutations, which can be used to better define species differences, even in closely related species (Rodriguez et al. 2003). These will give advantages in the retrieval of DNA from highly processed products. Besides, DNA similarity between species can be reduced as mtDNA is high in diversity and evolved compared to nuclear DNA (Saberi, 2016). Using suitable primer pairs, mitochondrial sequences have been amplified in many meat and fish species and the resulting differences used for species identification (Rodriguez et al. 2003). For this experiment, the primers were derived from a mitochondrial encoded gene for $12 \mathrm{~S}$ rRNA. This mitochondria was chosen in this lab work for speciesspecific primer as it has a suitable length and acceptable level of mutation.

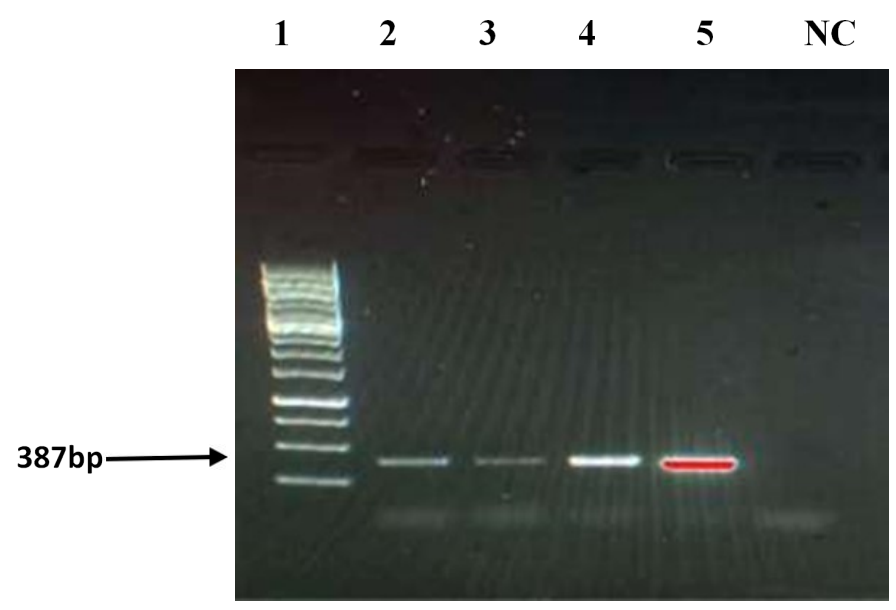

Figure 5. Detection of Porcine DNA in the cosmetic product. The arrow indicates the expected PCR product (387 bp). Lane 1: $1 \mathrm{~Kb}$ marker, Lane 2-4: extracted porcine DNA from cosmetic, Lane 5: PCR product from raw porcine DNA (positive control), Lane 6: negative control (NC).

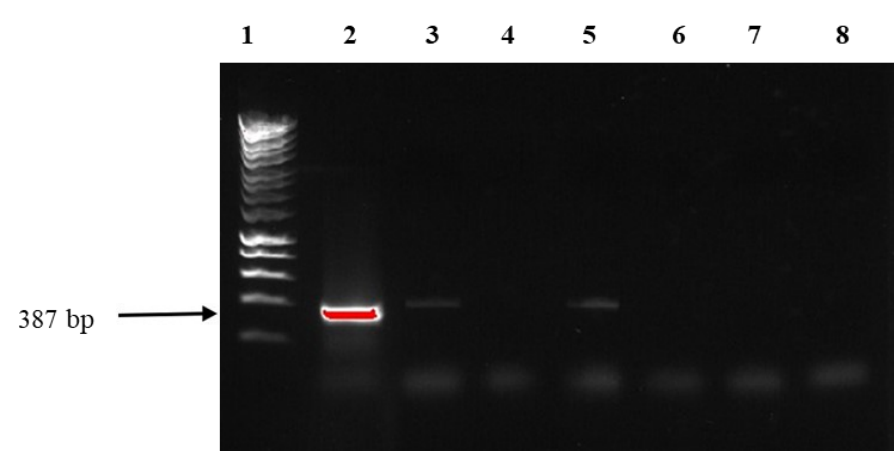

Figure 6. Screening of Porcine DNA in the five cosmetic products. The arrow indicates the expected PCR product $(387$ $\mathrm{bp}$ ). Lane 1: $1 \mathrm{~Kb}$ marker, Lane 2: DNA extracted from raw pork meat (positive control), Lane 3: Piggy Cosmetics, Lane 4: Brightening cream SPF15 with Halal logo, Lane 5: Hand cream, Lane 6: Whitening Face cream, Lane 7: Collagen Plus Vit E Day and Night cream, Lane 8: negative control (NC). 
Even though the cosmetic sample used in this research is a collagen-based product extracted from the pig's skin, it generally contained very low amounts of highly degraded porcine DNA. However, it still can be detected and amplified by the PCR-based technique. To validate the method, we screen four collagen-based cream products which one of that is labelled as Halal. The results showed the presence of PCR products in raw pork, piggy collagen cream and hand cream which contains collagen from an unknown source (Figure 6).

\section{Conclusion}

The detection of porcine DNA in cosmetic cream was successfully amplified at $387 \mathrm{bp}$. This study showed that the process of extraction and preparation for PCR reaction using the optimized method of PCR assay with species-specific primer (12SP and 12SFW) was successful and having a potential to be used for Halal authentication of cosmetics. In addition, although the porcine raw material in cosmetic cream undergoes highly physical and chemical processes, the amount of small DNA remains detected and the product remains haram according to Islamic regulation in Malaysia.

\section{Conflict of Interest}

The authors declare no conflicts of interest

\section{Acknowledgements}

Farah Najiha Fauzi is a beneficiary of Undergraduate student from Universiti Sains Islam Malaysia (USIM). This project was financially supported by the USIM Internal research grant (grant code: PPPI/ FST/0118/051000/15918).

\section{References}

Abd-Gani, S.S., Mustafa, S., Mohd Desa, M.N., Khairil Mokhtar, N.F., Hanapi, U.K., Zakaria, Z., Yahaya, N. and Wan Sulaiman, W.M.A. (2018). Detection of Porcine Adulteration in Cosmetic Cream Formulation via TaqMan Probe Real-Time Polymerase Chain Reaction. International Journal of Engineering and Technology, 7, 112-115.

Al-Ghananim and 'Izzat, Q. (2008). Al-Istihalah wa Ahkamuha fi al-Figh al-Islamiyy. Amman: Dar alNafais.

European Research and Fatwa Council. (2013). Meeting of the 23rd Meeting. June 25-28, 2013. Sarajevo. Bosnia.

Hanum, L., Windusari, Y., Setiawan, A., Adriansyah, F. and Mubarak, A.A. (2018). Comparison of CTAB Method and Wizard Genomic DNA Purification System Kit from Promega On DNA Isolation Of
Local Varieties Of Rice Of South Sumatera. Science and Technology Indonesia, 3(1), 26-29. https:// doi.org/10.26554/sti.2018.3.1.26-29

Jamaludin, M.A., Zaki, N.N.M, RamLi, M.A., Hashim, D.M. and Suhaimi, A.R. (2011). Istihalah: Analysis on The Utilization of Gelatin in Food Products. 2011 2nd International Conference on Humanities, Historical and Social Sciences, Singapore, 2011. Singapore: IACSIT Press.

Kim, Y.S., Yu, H.K., Lee, B.Z. and Hong, K.W. (2018). Effect of DNA extraction methods on the detection of porcine ingredients in halal cosmetics using realtime PCR. Applied Biological Chemistry, 61(5), 549555. https://doi.org/10.1007/s13765-018-0389-x

Mohammad, A.W., Suhimi, N.M., Abdul Aziz, A.G.K. and Jahim, J.M. (2014). Process for Production of Hydrolysed Collagen from Agriculture Resources: Potential for Further Development. Journal of Applied Sciences, 14(12), 1319-1323. https://doi.org/10.3923/jas.2014.1319.1323

Promega Corporation. (2017). Wizard Genomic DNA Purification Kit Technical Manual. Retrieved on August 12, 2018 from Promega website: https:// worldwide.promega.com/ resources/protocols/ technical-manuals/0/wizard-genomic-dnapurification-kit-protocol/.

Rodríguez, M.A., García, T., González, I., Asensio, L., Mayoral, B., López-Calleja, I. and Martín, R. (2003). Identification of Goose, Mule Duck, Chicken, Turkey, and Swine in Foie Gras by Species - specific Polymerase Chain Reaction. Journal of Agricultural and Food Chemistry, 51(6), 1524-1529. https:// doi.org/10.1021/jf025784+

Rodríguez, M.I., Barroso, L.G. and Sánchez, M.L. (2017). Collagen: A review on its sources and potential cosmetic applications. Journal of Cosmetic Dermatology, 17(1), 20-26. https://doi.org/10.1111/ jocd. 12450

Saberi, S. (2016). Porcine DNA detection in common tablet formulations and excipients. Malaysia: Universiti Sains Malaysia, MSc. Thesis.

Schrieber, R. and Gareis, H. (2007). Gelatin Handbook, p. 157-166. Weinhem: Wiley- VCH GMbH and Co. https://doi.org/10.1002/9783527610969

Yang, H. and Shu, Z. (2014). The Extraction of Collagen from Pig Skin. Journal of Chemical and Pharmaceutical Research, 6(2), 683-687.

Yorgancioglu, A. and Bayramoglu, E.E. (2013). Production of cosmetic purpose collagen containing antimicrobial emulsion with certain essential oils. Industrial Crops and Products, 44, 378-382. https:// doi.org/10.1016/j.indcrop.2012.11.013 